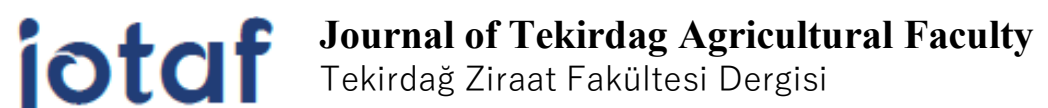

\section{Laktuloz İlave Edilerek Üretilen Sucukların Bazı Kalite Özelliklerinin Belirlenmesi}

Determining of Some Quality Properties of Sucuks Produced by Lactulose Addition

\author{
Harun URAN ${ }^{1 *}$, Hatice ŞANLIDERE ALOĞLU ${ }^{1}$, Bayram ÇETİN ${ }^{1}$
}

\section{Özet}

Laktuloz, probiyotik bakterilerin gelişimini teşvik eden prebiyotik özelliğe sahip bir disakkarittir. Gıda endüstrisinde kullanımı giderek artmakta olup, özellikle probiyotik gıdalarda kullanımı üzerinde durulmaktadır. Probiyotik et ürünleri, nispeten yeni ve et endüstrisinin çok iyi tanınmamış bir alanıdır. Ülkemizde bu türde üretilen ürünlerin başında fermente sucuk gelmektedir. Prebiyotik özelliğe sahip laktulozun, ülkemizde çok eski ylllardan beri üretilen ve sevilerek tüketilen fermente sucukların kalite özelliklerini olumlu yönde etkileyebileceğinden hareketle planlanan bu çalışmada, farklı konsantrasyonlarda (\%0.5, \%1 ve \%2) laktuloz ilavesiyle hazırlanan sucuklar, fermantasyon sürecinden sonra çeşitli özellikleri bakımından incelenmiştir. Elde edilen verilere göre laktuloz ilavesi sucukların kurumadde, kül ve $\mathrm{pH}$ değerlerinde farkl11ık oluşturmamış $(p>0.05)$, bununla birlikte \%2 laktuloz katkılı sucuklar laktuloz ilave edilen diğer gruplar ve edilmeyen kontrol grubuna göre su aktivitesi açısından önemli düzeyde düşük bulunmuştur $(p<0.05)$. Laktuloz katkısı ürünlerin $L^{*}$ değerini (parlaklık) arttırmış, $b^{*}$ değerini (sarlık) azaltmış, ancak istatistiksel olarak fark oluşturmamıştır $(p>0.05)$. Örneklerin $\mathrm{a}^{*}$ değeri (kırmızılık) de laktuloz ilavesiyle düşüş göstermiş ve bu durum kontrol grubu örneklere göre önemli düzeyde farklı $(p<0.05)$ bulunmuştur. Laktuloz katkısı sucukların tekstürel (sertlik, yapışkanlık, elastikiyet, çiğnenebilirlik ve bağl1lık) ve duyusal özelliklerinde farklılık yaratmamış, duyusal değerlendirmeyi yapan panel en çok \%2 laktuloz katkılı sucukları beğendiklerini ifade etmişlerdir. Ayrıca mikrobiyolojik analiz sonuçlarına göre fermantasyon süreci sonunda örneklerde Enterobacteriacea, Toplam Aerobik Mezofilik Bakteri (TAMB) ve maya-küf sayıları açısından fark belirlenmemiş, ancak Laktik Asit Bakterileri (LAB) sayısının laktuloz ilave edilen örneklerde kontrol örneklerine göre yüksek olduğu $(p<0.05)$ tespit edilmiştir. Sucuk örneklerinden taramalı elektron mikroskobu (SEM) ile görüntü de alınmış ve \%2 laktuloz ilave edilmiş sucuk örneklerinde basil yapıdaki bakterilerin yoğun olduğu görülmüştür.

Anahtar Kelimeler: : Laktuloz, Prebiyotik, Sucuk, Fiziksel kalite, Laktik asit bakterileri

\footnotetext{
1*Sorumlu Yazar/Corresponding Author: Harun URAN. Kırklareli Üniversitesi Mühendislik Fakültesi Gıda Mühendisliği Bölümü, Kırklareli, Türkiye. E-mail: harunuran@klu.edu.tr (D) OrcID: 0000-0002-3161-6698

${ }^{1}$ Hatice ŞANLIDERE ALOĞLU. Kırklareli Üniversitesi Mühendislik Fakültesi Gıda Mühendisliği Bölümü, Kırklareli, Türkiye. E-mail: haticealoglu@klu.edu.tr (iD) OrcID: 0000-0001-6004-0694

${ }^{1}$ Bayram ÇETIN. Kırklareli Üniversitesi Mühendislik Fakültesi Gıda Mühendisliği Bölümü, Kırklareli, Türkiye, E-mail: bayram.cetin@klu.edu.tr (DD OrcID: 0000-0003-1321-7746

Atıf/Citation: Uran, H., Şanlıdere Aloğlu, H., Çetin, B. Laktuloz İlave Edilerek Üretilen Sucukların Bazı Kalite Özelliklerinin Belirlenmesi. Tekirdağ Ziraat Fakültesi Dergisi, 18 (1), 58-70.

*Bu çalışmanın özeti 8. Uluslararası İleri Teknolojiler Sempozyumu'nda sunulmuștur.

CBu çalışma Tekirdağ Namık Kemal Üniversitesi tarafından Creative Commons Lisansı (https://creativecommons.org/licenses/by-nc/4.0/) kapsamında yayınlanmıştır. Tekirdağ 2021
} 


\begin{abstract}
Lactulose is a disaccharide with a prebiotic property that promotes the development of probiotic bacteria. It is increasingly used in the food industry, especially in the use of probiotic foods. Probiotic meat products are relatively new and not well known area of the meat industry. In the study, which is planned based on the possibility that lactulose can influence the quality properties of sucuks positively, sucuks prepared with the addition of lactulose at different concentrations $(0.5 \%, 1 \%$ and $2 \%)$ were examined according to their various properties following the fermentation process. According to the results, the addition of lactulose did not cause any difference in the dry matter, ash and $\mathrm{pH}$ values of the sucuks $(p>0.05)$, however, the water activity of the sucuks containing $2 \%$ lactulose were found significantly lower when compared to the other groups $(p<0.05)$. The addition of lactulose increased the $\mathrm{L}^{*}$ value (brightness) of the products, and decreased the $\mathrm{b}^{*}$ value (yellowness), but did not cause any statistical difference $(p>0.05)$. Lactulose supplementation did not cause any difference in the textural properties of samples, on the other hand sucuks with $2 \%$ lactulose were the most favored group for sensory evaluation. In addition, according to the results of microbiological analysis, there was no difference in the number of Enterobacteriacea, Total Aerobic Mesophilic Bacteria (TAMB) and yeast-mold in the samples at the end of the fermentation process. However, the count of Lactic Acid Bacteria (LAB) was found to higher $(p<0.05)$ in the samples with lactulose added compared to the control samples. In the SEM images of the samples, bacil bacteria were observed very dense in the $2 \%$ lactulose added sucuks.
\end{abstract}

Keywords: Lactulose, Prebiotic, Sucuk, Physical quality, Lactic acid bacteria 


\section{Giris}

Prebiyotik ifadesi "kolon bakterilerinden birinin veya az bir kısmının çoğalmasını ve/veya aktivitesini etkileyip yararlı bir etki oluşturan, sindirilemeyen gıda katkı maddesi” şeklinde tanımlanmaktadır (Gibson ve Roberfroid, 1995). Pek çok faydalarının olduğu bilinen bu maddelerin üzerinde en çok durulanları oligofruktoz, neoşeker, inülin gibi fruktooligosakkaritler (FOS) ve laktuloz, laktitol gibi galaktooligosakkaritlerdir (GOS) (Gülmez ve Güven, 2002).

Prebiyotikler içerisinde yer alan laktulozun, ilk kez 1930 yılında Montgomery ve Hudson tarafindan elde edildiği bildirilmektedir. Doğada doğal olarak mevcut olmayıp, süt ürünlerinin 1sıtılmasıyla laktozun izomerizasyonu sonucu oluşmakta ve UHT sütte \% 0.5 oranında bulunmaktadır (Montila ve ark., 2005). Laktuloz, yarı sentetik bir disakkarit türevi olup galaktozun fruktoza $\beta(1-4)$ glikozidik bağ ile bağlanması sonucu oluşur. İnce bağırsak kanalında değişikliğe uğramadan kalın bağırsağa geçerek öncelikle Bifidobakterler gibi metabolizma için çok faydalı olan probiyotik bakteriler tarafindan değerlendirilmekte ve bu bakterilerin gelişimini desteklemektedir. Hastalık yapıcı bakterilere karşı probiyotik bakterilerin etkisinin laktuloz katkısı ile önemli düzeyde desteklendiği belirtilmektedir. Bu nedenle fonksiyonel değeri yüksek bir prebiyotik olarak kabul edilmektedir. (Akalın, 2002; Kavas ve Kavas, 2011).

Fonksiyonel özelliği yanında teknolojik olarak da önem arz eden ve endüstriyel olarak da çeşitli proseslerde değerlendirilen bir katkıdır. Laktulozun gıda sanayiinde özellikle firıncılık ve süt ürünleriyle, çeşitli içeceklerde ve bazı özel gıdaların üretiminde kullanıldığı belirtilmektedir (Alpkent ve Göncü, 2005).

Laktulozun başta yoğurt ve peynir olmak üzere özellikle süt ürünlerinde kullanımı üzerine pek çok araştırma bulunmaktadır. Buna karşın bu katkı maddesinin et ürünlerinde kullanımı üzerine çok az çalışma bulunmaktadır. Son yıllarda fermente ürünlerde katkı maddesi olarak laktuloz, fruktooligosakkarit, galaktooligosakkaritler gibi prebiyotik sakkaritlerin kullanımı üzerinde durulmaktadır. Bu maddelerin özellikle bifidobakterlerin gelişimini teşvik ettiği bilinmektedir (Bağdatlı ve Kundakçı, 2013).

Araştırmamızda prebiyotik özelliğe sahip bir disakkarit olan laktulozun, sucuk üretiminde kullanılması amaçlanmıştır. Fermantasyon işlemi, eti uzun süre muhafaza etmek ve yeni ürün üretmek amaciyla kullanılan oldukça eski yöntemlerdendir. Günümüzde farklı tür etlerin kullanımına olanak sağlamak, ürün çeşitliliğini artırmak ve sağlık açısından faydalı ürünler üretmek amacıyla fermantasyon işleminde mikroorganizma, et ve teknoloji birlikte kullanılmaktadır (Geçgel ve ark., 2016). Fermantasyon esnasında ürün çeşitli fiziksel, biyokimyasal, mikrobiyolojik değişimler geçirmekte ve üründe istenilen tat, koku ile tekstür oluşmaktadır (Gökalp ve ark., 1998).

Sucuk, Türk Gıda Kodeksi ilgili tebliğine göre büyükbaş ve/veya küçükbaş hayvan karkas etlerinin ve yağlarının kıyılarak lezzet vericiler ile karıştırıldıktan sonra doğal veya yapay kılıflara doldurularak belirli koşullarda fermentasyon ve kurutma işlemleri uygulanarak kesit yüzeyi mozaik görünümünde olan 1sıl işlem uygulanmamış fermente et ürünü olarak tanımlanmaktadır (Anonim, 2019). Ülkemiz standart kuruluşuna (TSE) göre ise geleneksel Türk sucuğu, mevzuatına uygun kombina ve mezbahalarda kesilen kasaplık hayvanların gövde etlerinden hazırlanan sucuk hamurunun, doğal veya yapay kılıflara doldurulup, olgunlaştırma işlemine tabi tutulması ile elde edilen et ürünü olarak tanımlanmaktadır (TSE, 2002).

Fermente et ürünleri Avrupa ülkeleri başta olmak üzere dünyada yaygın bir şekilde üretilmekte ve tüketilmektedir. Türklere özgü fermente bir et ürünü olan sucuk, ülkemizde de yoğun olarak üretilmesine rağmen halen standart üretim koşulları belirli olmayan bir ürün durumundadır. Geleneksel Türk sucukları yaygın olarak küçük ve orta ölçekli işletmelerde hava akımı beraberinde, geleneksel yöntemler takip edilerek üretilmektedir. Bu ürünün çeşitleri içerisinde fermente sucukların daha fazla tercih edilmesinde ve beğenilmesinde, fermantasyonun bu ürünlerde hoşa giden lezzet, aroma, renk ve yapısal nitelikler ile nispeten uzun bir raf ömrü kazandırmasının etkili olduğu belirtilmektedir (Kara ve Akkaya, 2010).

Sucuklarda arzu edilen yapı, lezzet, aroma ve renk, sucuk hamurundaki spontan mikroorganizmaların, fermantasyon esnasında enzimatik ve biyokimyasal reaksiyonları aracılığı ile şekillenmektedir. Sucuğun olgunlaşması ve buna bağlı olarak kalite niteliklerinin gelişmesini sağlayan en önemli etkenler mikrobiyel aktivitelerdir. Olgunlaşmada rol alan başlıca bakteriler laktobasiller, pediokoklar, mikrokoklar ve stafilokoklardır. 
Sucuklarda arzu edilen kalite kriterlerinin oluşması, olgunlaşmada rol oynayan bu bakteri gruplarının florada bulunma düzeyleri ve oluşturdukları etkilerle yakından ilişkilidir (Gözübüyük ve Özdemir, 2005).

Sucuk üretiminde olgunlaşmayı hızlandırmak maksadıyla starter kültür ilavesi yapılabildiği gibi, sucuk hamurunda bulunan doğal mikrofloranın çoğu zaman istenen neticeyi sağladığı bildirilmektedir. Bununla birlikte genellikle endüstriyel üretimde çeşitli şekerler (glukoz, sakkaroz ve bazen laktoz) sucuk hamuruna ilave edilmektedir. Fermantasyon ve olgunlaştırma aşamalarında, laktik asit bakterileri öncelikli enerji kaynakları olan glukozu, pH azalmasını sağlayan laktik aside dönüştürmektedirler. Ortamdaki bu asitleşme, düşük pH'ya az da olsa dirençli olan patojenik ve istenmeyen bakterilerin inhibisyonu açısından da önemli olup, sucuğun tipik organoleptik karakterinin gelişmesini sağlamaktadır (Bilge, 2010).

Araştırmamızda farklı konsantrasyonlarda prebiyotik bir bileşik olan laktuloz ilave edilerek üretilen sucuklar, fermantasyon sürecini takiben kalite özelliklerinin bir katkı olan laktulozun, sucuğun fermantasyon sürecine olan katkısı belirlenmeye çalışılmışıtır.

\section{Materyal ve Metot}

Sucuk üretimi için kullanılacak malzemeler (sığır eti, kuyruk yağı, baharatlar) Kırklareli'de faaliyet gösteren özel bir et işleme tesisinden (Dere Et ve Et Ürünleri) temin edilmiş ve üretim de aynı tesiste yapılmıştır. Öte yandan üretimde kullanılan $\mathrm{NaNO}_{2}$ ve Na-askorbat Merck'ten (Almanya), laktuloz Sigma'dan (L7877, ABD) alınmıştır. Tüm analizler Kırklareli Üniversitesi, Gıda Mühendisliği Bölümü laboratuarlarında (Kırklareli, Türkiye) yapılmıştır.

\subsection{Sucuk üretimi}

Sucuk üretimi için ana bileşenleri sığır eti (\%80) ve kuyruk yağı (\%20) oluşturmuştur. Bu ana karışımın kg'1 başına ilave edilen diğer bileşenler şunlardır: kırmızı biber (7 g), tuz (25 g), sarımsak (toz) (10 g), karabiber (5 g), kimyon $(9 \mathrm{~g})$, yenibahar ( $2.5 \mathrm{~g})$, Na-askorbat $(0.45 \mathrm{~g})$ ve NaNO2 $(0.15 \mathrm{~g})$. Üretimde öncelikle et ve dondurulmuş kuyruk yağı bir kıyma makinesinde (Arı Makine, İstanbul, Türkiye) yaklaşı 1-1.5 $\mathrm{cm}$ boyutlarında olacak şekilde çekilmiştir. Daha sonra tuz (NaNO2 ilave edilip karıştırılmış şekilde), baharatlar, Na-askorbat eklenmiş ve kıyılmış et ile karıştııılmıştır. Karışım dinlendirildikten sonra $\left(0-40 C^{\prime}\right.$ de 12 saat), dört gruba ayrılmış, bunlardan üçüne laktuloz eklenmiş (\%0.5, 1 ve 2) ve sonuncusu ise kontrol olarak ayrılmıştır. Elde edilen sucuk hamuru el yardımıyla iyice karıştırılarak homojen hale getirilmiştir. Hamur tekrar ince gözenek çapına sahip aynadan geçirilerek doluma hazır hale getirilmiş̧tir. Sucuk hamuru, önceden ıslatılmış doğal sığır bağırsaklarına doldurulup bağlanarak askıya asılmıştır. Hazırlanan sucuklar önce 3 gün boyunca $25 \pm 1 \mathrm{oC}$ ve $\% 90$ RH'de ve sonra da 12 gün boyunca $20 \pm 1$ oC'de ve $\% 80-85$ RH'de bekletilerek olgunlaştırılmıştır. Bu sürenin sonunda olgunlaşma süreci tamamlanan sucuklar analize alınmıştır. Üretim 2 tekerrürlü yapılmış ve analizler paralelli olarak yürütülmüştür.

\subsection{Analizler}

\subsubsection{Fizikokimyasal analizler}

Sucuk örneklerinin kurumadde ve kül analizleri AOAC (1990)'a göre yapılmıştır. pH ölçümlerinde, homojenize edilmiş örneklerden $10 \mathrm{~g}$ alınmış ve $100 \mathrm{ml}$ saf su içerisinde homojenizatör kullanılarak $1 \mathrm{dk}$ homojenize edildikten sonra pH-metre (WTW Inolab Level 2) probu daldırılmıştır ve değerler kaydedilmiştir (AOAC, 1984).

$\mathrm{Su}$ aktivitesi ölçümü, su aktivitesi tayin cihazı (Novasina LabSwift, İsviçre) kullanılarak $25^{\circ} \mathrm{C}$ 'de gerçekleştirilmiştir (Frei ve ark., 2012).

Sucukların CIE L* (parlaklık), a* (kırmızılık) ve b* (sarılık) değerleri CR-400 Conica Minolta (Minolta, Osaka, Japonya) Renk Ölçüm Cihazı kullanılarak belirlenmiştir. Eşit boylarda kesilen her örnekten beş ölçüm yapıldıktan sonra aritmetik ortalamaları hesaplanmıştır (Gokoglu ve ark, 2010).

Pişirme kaybı tespiti için sucuklar elektrikli ızgarada (Simbo, Türkiye) yaklaşı1k $180^{\circ} \mathrm{C}$ 'de 5 dakika süre ile pişirilmiştir. Sucuklarda pişirme kaybı, pişirmeden önceki sucuk ağırlığının pişmiş sucuk ağırlı̆ıından çıkarılıp, çiğ sucuk ağırlığına bölümünün yüz ile çarpımı sonucu tespit edilmiştir (Bostan ve ark., 2001). 
Sucuk örneklerinin Tekstür Profil Analizi (TPA), tekstür analiz cihazı (TA.HD Plus Stable Micro Systems Ltd., Surrey, İngiltere) kullanılarak gerçekleştirilmiş̧ir. Ölçüm için $36 \mathrm{~mm}$ çapında alüminyum silindir prob (SMS P/36, 36mmdiameter, TA.HD Plus StableMicro Systems Ltd., Surrey, İngiltere) kullanılmıştır. Ölçüm için Güç-zaman deformasyon eğrileri, $30 \mathrm{~kg}$ 'lık yük hücresi uygulanarak elde dilmiştir. Ölçümleri yapılacak sucuk örnekleri, buzdolabında bekletilmiş ve çıkarıldıktan sonra $1 \mathrm{~cm}$ yüksekliğinde ve $1.5 \mathrm{~cm}$ kenar uzunluğunda eşit boylarda kesilerek cihaza yerleştirilmiş̧ir. Cihazın ön test, test ve son test hızı sırasıyla $1,5 \mathrm{ve} 1 \mathrm{~mm} / \mathrm{s}$ olarak ayarlanmış̧ır. Güç-uzaklık eğrileri kaydedilmiştir ve kuvvet ve maksimum kuvvet pikinin mesafesi ile eğriyi temsil eden mekanik parametreler (sertlik, çiğnenebilirlik, yapışkanlık, elastikiyet ve koheziflik) belirlenmiştir. Ölçümler her örnek için 5'er kez tekrar edilmiş ve ortalama değerler kaydedilmiş̧ir (Dertli ve ark., 2016).

\subsubsection{Mikrobiyolojik analizler}

Sucukların fermantasyon sürecinin 7. ve 15. günlerinde Entereobacteriaceae, Toplam aerobik mezofilik bakteri (TAMB), maya-küf ve Laktik asit bakterileri (LAB) sayımı yapılmıştır. Entereobacteriaceae analizi Violet Red Bile Dextrose Agar (VRBDA, Oxoid, England) kullanılarak dökme plak yöntemi ile $37^{\circ} \mathrm{C}$ 'de 24 saat inkübe edilerek yapılmıştır (TSE, 2018). TAMB sayımı için hazırlanan örnekler Plate Count Agar (PCA, Oxoid) üzerine dökme plak yöntemi ile ekilmiş ve $30^{\circ} \mathrm{C}$ 'de $24-48$ saat inkübe edilmiş̧ir (TSE, 2014a) Toplam maya-küf sayımı Rose Bengal Chloramphenicol Agar (Oxoid) kullanılarak yayma plak yöntemi ile $25^{\circ} \mathrm{C}$ 'de 5-7 gün inkübe edilerek yapılmıştır (TSE, 2014b). LAB sayımı için Man Rogosa Sharpe Agar (MRS)'a ekim yapılmış ve örnekler $37^{\circ} \mathrm{C}$ 'de 72 saat süre ile anaerob koşullarda inkübe edilerek sayımları gerçekleştirilmiştir (Gimeno ve ark., 2001). Sayımlardan elde edilen sonuçlar log kob g ${ }^{-1}$ olarak ifade edilmiştir.

\subsubsection{Duyusal analizler}

Sucukların çeşitli duyusal özelliklerinin (Renk, koku, lezzet, doku, genel kabul) belirlenmesi amacıyla, sonuçların $10 \mathrm{~cm}$ uzunluğunda çizgilere yapıldığı değerlendirme skalası kullanılmıştır. Skalaya göre 0: kabul edilemez ve 10:mükemmel değerlerini temsil etmektedir. Değerlendirme sonucunda işaretlemeler cetvel yardımıyla ölçülerek kaydedilmiştir. Duyusal panel, sucuk tüketim alışkanlı̆ğ olan 10 kişilik bir panelist grubu tarafından yürütülmüştür (Bingöl ve ark., 2015).

\subsubsection{Taramalı elektron mikroskobunda (SEM) görüntü alınması}

Sucukların Taramalı Elektron Mikroskobu (SEM) ile mikro yapılarının incelenmesinde Yılmaz ve ark. (2015)'ın belirlemiş olduğu metot kullanılmıştır. Yüksek vakum altında çalışan Fei marka (FEI, Quanta feg 250, USA) SEM ile numunelerden 10.000 büyütme gücünde görüntü alınmıştır. İkincil elektron görüntüleri 5 kV'lık hızlanan bir voltajda kazanılmıştır. Ölçüm öncesi sucukların iç kısımlarından homojen bir şekilde $1 \mathrm{~mm}$ kalınlığında ve $0.5 \mathrm{~cm}$ kenar uzunluğuna sahip boyutlarda örnek alınmış ve cihaza yerleştirilmiştir.

\subsection{5. İstatistik analiz}

Denemeler iki tekerrürlü ve ikişer paralelli olarak yürütülmüştür. Elde edilen sonuçlara SPSS (18.0; SPSS Statistics/IBM, Armonk, NY) paket programı kullanılarak varyans analizi uygulanmış ve önemli bulunan varyasyon kaynaklarından farklı etkide bulunanı belirlemek amacıyla ortalamalar Duncan Çoklu Karşılaştırma Testi ile karşılaştırılmışıtır $(p<0.05)$

\section{Araştırma Sonuçları ve Tartışma}

Araştırma neticesinde sucuk örneklerine ait çeşitli fizikokimyasal özellik bulguları Tablo 1'de verilmiş̧ir. Fermantasyon süreci sonunda laktuloz ilave edilmeyen ve $\% 0.5, \% 1$ ve $\% 2$ laktuloz içeren sucuk örneklerinin kurumadde içerikleri sırasıyla \%64.17; 63.93; 61.11; 61.72 olarak tespit edilmiştir. Ürünlerde su içeriğinin Türk Sucuğu Standardı'nda verilen sınırın (\%40) altında olduğu görülmektedir (TSE, 2002). Ayrıca laktuloz ilavesi ürünlerin kurumadde içeriklerinde az da olsa azalma meydana getirmesine rağmen (Tablo 1), bu durum istatistiki olarak fark oluşturmamıştır $(p>0.05)$. 
JOTAF/ Journal of Tekirdag Agricultural Faculty, 2021, 18(1)

Tablo 1. Sucuk Örneklerinin Analiz Sonuçları $1^{1}$

Table 1. Analysis Results of Sucuks $1^{1}$

\begin{tabular}{|c|c|c|c|c|}
\hline \multirow{2}{*}{ Analizler } & \multicolumn{4}{|c|}{ Örnek* } \\
\hline & $\mathbf{A}$ & B & $\mathbf{C}$ & D \\
\hline Kuru madde (\%) & $64.17 \pm 2.52^{\mathrm{a}}$ & $63.93 \pm 1.82^{\mathrm{a}}$ & $61.11 \pm 1.87^{\mathrm{a}}$ & $61.72 \pm 1.75^{\mathrm{a}}$ \\
\hline Kül (\%) & $5.82 \pm 0.43^{\mathrm{a}}$ & $6.07 \pm 1.07^{\mathrm{a}}$ & $6.65 \pm 0.42^{\mathrm{a}}$ & $6.71 \pm 0.27^{\mathrm{a}}$ \\
\hline Su Aktivitesi (a $\left.a_{w}\right)$ & $0.876 \pm 0.00^{\mathrm{a}}$ & $0.875 \pm 0.00^{\mathrm{a}}$ & $0.872 \pm 0.00^{\mathrm{a}}$ & $0.849 \pm 0.00^{\mathrm{b}}$ \\
\hline pH değeri & $5.41 \pm 0.03^{\mathrm{a}}$ & $5.24 \pm 0.02^{\mathrm{a}}$ & $5.23 \pm 0.02^{\mathrm{a}}$ & $5.17 \pm 0.06^{\mathrm{a}}$ \\
\hline
\end{tabular}

*A:Kontrol; B: \%0.5 laktuloz ilaveli; C: \%1laktuloz ilaveli; D: \%2 laktuloz ilaveli

${ }^{1}$ Değerler \pm standart sapmayı ihtiva etmektedir. Satırda aynı harflerle işaretlenen ortalamalar istatistiksel olarak birbirinden farklı değildir ( $p>0.05)$

*A:No lactulose added; B: 0.5\% lactulose added; C: 1\% lactulose added; D: 2\% lactulose added

${ }^{1}$ Values include \pm standard deviation. The averages marked with the same letters in rows are not statistically different from each other $(p>0.05)$

Prebiyotik özellikte ürün katkılı fermente sucuk üretimi üzerine çalışmaya rastlanmamış, ancak fermente sucukların değişik özellikte katkı ilavesi ve koşullarda üretimi üzerine çeşitli çalışmaların bulunduğu gözlenmiştir. Ayrıca fermente sucuk olarak satışa sunulan sucukların da kalitelerinin incelendiği araştırmalar mevcuttur. İstanbul piyasasında fermente sucuk olarak satılan sucukların kalitelerinin araştırıldığ bir çalışmada, toplam 30 adet sucuk örneğinin 6 tanesinin su içeriğinin çalışmamızdaki sonuçlara benzer şekilde \%35-40 arasında olduğu belirlenmiştir (Pehlivanoğlu ve ark., 2015). Yine başka bir çalışmada Kara ve ark. (2012) farklı oranlarda manda eti ve yağ kullanarak ürettikleri fermente sucuklarda 12. gün sonunda su içeriklerinin \% 38.09 ila 40.82 arasında değiştiklerini bildirmişlerdir. Öksüztepe ve ark. (2011)'nin bildirdiği bir araştırmada ise, Elazığ'da tüketime sunulan 100 adet fermente sucuk, farklı özellikleri açısından incelenmiş ve araştırma neticesinde örneklerin nem içeriklerinin ortalama \%38.75 olduğunu belirtmişlerdir. Dertli ve ark. (2016), farklı starter kültür ve fermantasyon şartları deneyerek ürettikleri fermente sucukları, fermantasyon süreci boyunca fizikokimyasal ve tekstürel özellikleri bakımından incelemişlerdir. Fermantasyonun 16. gününde oluşturdukları farklı sucuk gruplarının kurumadde içeriklerinin \%51.23; \%57.88 ve \%63.27 düzeyinde olduğunu gözlemlemişlerdir.

Çalışmamızda kontrol grubu sucuk örneklerinin kül içeriklerinin \%5.82 olduğu, laktuloz ilavesine paralel olarak kül içeriğinde de artış olduğu ve en yüksek kül içeriğinin \%2 laktuloz içeren örnekler olduğu (\%6.72) belirlenmiştir. Ancak kül miktarında görülen bu artış, örnekler arasında istatistiki olarak fark meydana getirmemiştir $(p>0.05)$.

Fermente sucukların kalitelerinin belirlenmesi üzerine yapılan bir çalışmada, örneklerin (100 adet) kül içeriklerinin \%6.18 ile \%5.39 arasında değiştiği belirlenmiştir (Öksüztepe ve ark., 2011). Sonuçlar çalışmamız ile paralellik göstermektedir.

Ürettiğimiz sucuk örneklerinin fermantasyon sonundaki pH değerleri sırasıyla 5.41; 5.24; 5.23 ve 5.17 olarak bulunmuş ve örnekler arasında istatistiki olarak fark tespit edilmemiştir $(p>0.05)$.

Fermente sucuklarda $\mathrm{pH}$ değeri, fermantasyon prosesi boyunca değişime uğrayan ve prosesin seyrini tayin eden önemli bir kriterdir. Fermantasyonun ilk aşamasında düşüş gözlenir ve sonra tekrar artışa geçer. Pehlivanoğlu ve ark. (2015) yaptıkları araştırmada fermente sucukların \%26'sının pH değerinin 5.4 ile 6 arasında olduğunu, büyük çoğunluğunun ise çalışmamızdaki gibi 5 ile 5.4 arasında bir pH değerine sahip olduğunu bildirmişlerdir. Öksüztepe ve ark. (2011) yaptıkları çalışmada fermente sucukların pH değerlerinin ortalama 5.18 olduğunu belirtmişlerdir. Bununla birlikte genel olarak fermente sucuklar üzerine yapılan çalışmalarda pH değerlerinin çalışmamıza benzer olduğu bildirilmektedir (Soyer ve ark., 2005; Bozkurt ve Erkmen, 2007; Kara ve ark., 2012; Dertli ve ark., 2016).

Araştırmamızda sucuk örneklerinin su aktivitesi $\left(\mathrm{a}_{\mathrm{w}}\right)$ değerleri 0.876 (kontrol grubu) ila 0.849 (\%2 laktuloz ilaveli grup) arasında belirlenmiştir. Laktuloz ilavesi sucuk örneklerinin $\mathrm{a}_{\mathrm{w}}$ değerlerinde düşüş meydana getirmiş ve bu düşüş kontrol, $\% 0.5$ ve $\% 1$ laktuloz ilaveli gruplar arasında fark oluşturmazken, \% 2 laktuloz ilaveli grup diğer gruplara göre önemli derecede $(p<0.05)$ farklı bulunmuştur. Bu durum, bir disakkarit olan laktulozun suyu bağlaması ve bu sayede $\mathrm{a}_{\mathrm{w}}$ değerini düşürmesi şeklinde açıklanabilir. 
Hampikyan ve Uğur (2007), nisin ilavesinin Türk tipi fermente sucukta L. monocytogenes üzerine etkisini inceledikleri çalışmalarında, farklı oranlarda nisin ilave ederek oluşturdukları sucuk örneklerinin su aktivitesi değerlerinin fermantasyonun 1. gününde 0.985 olduğunu ve 15. gün sonunda bu değerin 0.93 seviyesinin altına düştüğünü bildirmişlerdir. Yine Soyer ve ark. (2005) farklı işleme koşullarının fermente sucukların özellikleri üzerine etkilerini inceledikleri araştırmalarında, 10. gün sonunda sucukların su aktivitesi değerlerinin 0.90'ın altına düştüğünü bildirmişlerdir.

Sucuk örneklerinin renk değerlerine ait bulgular Tablo 2'de verilmiştir. Elde edilen verilere göre laktuloz ilavesi örneklerin $a^{*}$ değerleri (kırmızılık) dışında renk özellikleri üzerinde farklılık oluşturmamıştır. L* değeri (parlaklık) örneklerde sırasıyla $48.71 ; 51.82 ; 50.08$ ve 50.41 olarak bulunmuştur. Laktuloz ilavesi örneklerin parlaklığında artış oluştursa da bu artış istatistiki olarak farklı bulunmamıştır $(p>0.05)$. Örneklerin a* değerleri incelendiğinde kontrol grubu örneklerde 17.97 değeri gözlenirken, laktuloz ilave edilen örneklerde sirasıly 14.73; 12.92 ve 12.77 değerleri belirlenmiştir. Laktuloz ilavesi örneklerin kırmızılığını arttırmış ve bu durum kontrol grubu örneklere göre fark yaratmıştır $(p<0.05)$. Diğer taraftan laktuloz içeren gruplar kendi içerisinde fark oluşturmamıştır $(p>0.05)$. Örneklerin $\mathrm{b}^{*}$ değerleri (sarılık) incelendiğinde, en düşük değerin \%1 laktuloz ilaveli grupta (6.86), en yüksek değerin ise kontrol grubunda (8.20) olduğu görülmektedir. Laktuloz ilavesi örneklerin az da olsa sarılık değerlerinde artış oluşturmuş, ancak tüm gruplar istatistiki olarak farklı bulunmamıştır $(p>0.05)$.

Tablo 2. Sucuk Örneklerinin Analiz Sonuçları $2^{1}$

Table 2. Analysis Results of Sucuks $2^{1}$

\begin{tabular}{|c|c|c|c|c|c|}
\hline \multirow{2}{*}{\multicolumn{2}{|c|}{ Analizler }} & \multicolumn{4}{|c|}{ Örnek* } \\
\hline & & $\mathbf{A}$ & $\mathbf{B}$ & $\mathbf{C}$ & $\mathbf{D}$ \\
\hline \multirow{3}{*}{ Renk } & $\mathbf{L}^{*}$ & $48.710 \pm 1.515^{\mathrm{a}}$ & $51.820 \pm 1.621^{\mathrm{a}}$ & $50.082 \pm 1.430^{\mathrm{a}}$ & $50.415 \pm 2.791^{\mathrm{a}}$ \\
\hline & $a^{*}$ & $17.970 \pm 0.959^{\mathrm{a}}$ & $14.737 \pm 0.925^{\mathrm{b}}$ & $12.920 \pm 1.664^{\mathrm{b}}$ & $12.772 \pm 1.444^{b}$ \\
\hline & $\mathbf{b}^{*}$ & $8.205 \pm 0.489^{a}$ & $7.735 \pm 0.601^{\mathrm{a}}$ & $6.865 \pm 1.126^{\mathrm{a}}$ & $7.280 \pm 0.893^{\mathrm{a}}$ \\
\hline \multicolumn{2}{|c|}{ Pişirme Kaybı (\%) } & $20.285 \pm 0.989^{\mathrm{a}}$ & $18.410 \pm 1.796^{\mathrm{ab}}$ & $16.595 \pm 2.506^{b}$ & $15.422 \pm 2.060^{b}$ \\
\hline
\end{tabular}

*A:Kontrol; B: \%0.5 laktuloz ilaveli; C: \%1laktuloz ilaveli; $D: \% 2$ laktuloz ilaveli

${ }^{1}$ Değerler \pm standart sapmayı ihtiva etmektedir. Satırda aynı harflerle işaretlenen ortalamalar istatistiksel olarak birbirinden farklı değildir $(p>0.05)$

*A:No lactulose added; B: 0.5\% lactulose added; C: $1 \%$ lactulose added; D: 2\% lactulose added

${ }^{1}$ Values include \pm standard deviation. The averages marked with the same letters in rows are not statistically different from each other $(p>0.05)$

Bozkurt (2007) kekik ve susam yağı kullanarak ürettiği fermente sucukların, olgunlaşmanın 15. gününde L* değerlerinin 39.28-41.14; $\mathrm{a}^{*}$ değerlerinin 11.57-12.85 ve $\mathrm{b}^{*}$ değerlerinin ise 11.99-12.36 arasında değiştiğini bildirmiştir. Başka bir çalışmada farklı işleme koşullarında işlenen sucukların 10. gün sonunda $L^{*}$ değerleri 36-45 arasında, a* değerleri 12-18 arasında ve $b^{*}$ değerleri de 14-20 arasında değiştiği bildirilmektedir (Üren ve Babayiğit, 1996). Siyah havuç eklenerek üretilen fermente sucukların kalite özelliklerinin incelendiği çalışmada ise, örneklerin $L^{*}$ değerlerinin 45.72-42.40, $a *$ değerlerinin 17.20-12.13 ve b* değerlerinin de 17.43-9.64 arasında değiştiği tespit edilmiştir (Ekici ve ark., 2015).

Araştırmamızda laktuloz ilavesinin, sucukların pişirme kayıplarında azalma meydana getirdiği belirlenmiştir (Tablo 2). Kontrol grubu örneklerde pişirme kayb1 \%20.28 olarak bulunurken, bu değer laktuloz ilaveli gruplarda sırasıyla $18.41 ; 16.59$ ve 15.42 olarak belirlenmiştir. Laktulozun \%1 ve \%2 oranında kullanıldı̆̆ı sucuk örnekleri, pişirme kayıplarındaki azalma açısından kontrol grubu örneklerine göre önemli derecede farklı $(p<0.05)$ bulunmuştur. Su aktivitesindeki azalmaya paralel olarak pişirme kayılarında benzer durumun gözlenmesi, yani laktulozun suyu bağlayarak pişirme kayıplarında düşüş meydana getirmesi normal olarak değerlendirilebilir. Ancak ticari açıdan düşünüldüğünde, üründe pişirme kayıplarının azaltılması önemli bir kazanım olarak kabul edilebilir.

Çalışmamızda farklı konsantrasyonlarda eklenen laktulozun, fermente sucukların tekstürel özelliklerini (sertlik, çiğnenebilirlik, yapışkanlık, elastikiyet ve koheziflik) önemli düzeyde etkilemediği belirlenmiş ve tekstürel özelliklere ait değerler Tablo 3'de verilmiştir. Laktuloz konsantrasyonundaki artış örneklerin sertlik değerlerinde 
artış meydana getirmiş, bu değer kontrol grubu örneklerde $22.03 \mathrm{~N}$ ile en düşük düzeyde bulunurken, \%2 laktuloz ilaveli örneklerde $24.48 \mathrm{~N}$ ile en yüksek düzeyde tespit edilmiştir. Başka bir ifadeyle laktuloz örnekleri daha sert yapıya dönüştürmüş ancak bu durum istatistiki olarak fark oluşturmamıştır $(p>0.05)$. Bu duruma paralel olarak laktuloz ilavesi örneklerin çiğnenebilirliğini azaltmış, ancak benzer şekilde istatistiki fark oluşturmamıştır $(p>0.05)$.

Laktuloz, sucukların yapışkanlığını farklı şekillerde etkilemekle birlikte genel olarak arttırmıştır. Ancak bütün gruplar arasında yapışkanlık değeri bakımından istatistiki açıdan bir fark gözlenmemiştir $(p>0.05)$.

Aynı şekilde laktuloz ilavesi örneklerin elastikiyet ve koheziflik özelliklerinde artış meydana getirmiştir. Bununla birlikte yine örnekler arasında elastikiyet ve koheziflik bakımından istatistiki fark oluşmamıştır $(p>0.05)$.

Tablo 3. Sucuk Örneklerinin Tekstürel Analiz Sonuçlart ${ }^{1}$

Table 3. Textural Analysis Results of Sucuks ${ }^{1}$

\begin{tabular}{ccccc}
\hline \multirow{2}{*}{ Tekstürel Özellik } & \multicolumn{4}{c}{ Örnek* $^{*}$} \\
\cline { 2 - 5 } & $\mathbf{A}$ & $\mathbf{B}$ & $\mathbf{C}$ & D \\
\hline Sertlik (N) & $22.03 \pm 3.827$ & $23.41 \pm 2.665$ & $24.02 \pm 3.521$ & $24.48 \pm 2.412$ \\
Çiğnenebilirlik & $13.69 \pm 1.792$ & $11.92 \pm 1.467$ & $11.62 \pm 1.630$ & $11.26 \pm 1.548$ \\
Yapışkanlık (g.s) & $-30.51 \pm 5.907$ & $-25.39 \pm 7.275$ & $-28.86 \pm 5.085$ & $-29.09 \pm 7.197$ \\
Elastikiyet (mm) & $0.73 \pm 0.100$ & $0.77 \pm 0.044$ & $0.82 \pm 0.063$ & $0.82 \pm 0.077$ \\
Koheziflik & $0.67 \pm 0.011$ & $0.68 \pm 0.022$ & $0.69 \pm 0.024$ & $0.70 \pm 0.008$ \\
\hline
\end{tabular}

*A:Kontrol; B: \%0.5 laktuloz ilaveli; C: \%1laktuloz ilaveli; D: \%2 laktuloz ilaveli

${ }^{1}$ Değerler \pm standart sapmay ihtiva etmektedir.

*A:No lactulose added; B: 0.5\% lactulose added; C: $1 \%$ lactulose added; D: 2\% lactulose added

${ }^{1}$ Values include \pm standard deviation.

Ekici ve ark. (2015) tarafından yapılan çalışmada fermente sucuk örneklerinin tekstürel özelliklerinde çalışmamıza benzer bulgulara rastlanmıştır. Araştırmacılar örneklerin yapışkanlıklarının -10.99 ile -86.83 g.s. arasında; elastikiyetlerinin 0.50-0.61 arasında; bağlılık değerlerinin 0.44-0.61 arasında ve sertlik değerlerinin de 463.37-798.76 $\mathrm{g}$ arasında değiştiğini bildirmişlerdir.

Dertli ve ark., (2016) de farklı şekillerde ürettikleri fermente sucukların tekstürel özelliklerinden sertlik değerinin 3998 ila 25,484 g arasında; yapışkanlık değerinin -155.4 ile -13.6 g.s. arasında; elastikiyet değerinin 0.499 ile $0.699 \mathrm{~mm}$ arasında ve bağlılık değerinin de 0.266 ile 0.517 arasında değiştiğini belirlemişlerdir.

Çalışmamızda üretilen sucuklar, fermantasyonun 7. ve 15. günlerinde mikrobiyolojik açıdan takip edilmiş ve bulgular Tablo 4'de verilmiştir. 7. gün sonunda sucuklarda 1.63 ile $2.21 \mathrm{log} \mathrm{kob} \mathrm{g}^{-1}$ arasında değişen Enterobacteriaceae sayısı, 15. gün sonunda tüm örneklerde sıfırlanmıştır. TAMB sayıları incelendiğinde, 7. Günde 3.66-3.82 log kob g ${ }^{-1}$ arasında değişen sayı, 15. günde 3.54-4.29 $\log \mathrm{kob} \mathrm{g}^{-1}$ arasında seyretmiş, bu süre sonunda en yüksek sayı kontrol grubu örneklerde belirlenmiştir. Bununla birlikte örnekler arasında TAMB sayıları açısından fark gözlenmemiştir $(p>0.05)$. Fermantasyonun 7. Gününde maya-küf sayısı en yüksek olan örneğin \%0.5 laktuloz ilave edilen sucuklar (4.57 log kob g$\left.{ }^{-1}\right)$, en düşük olan örneğin ise \% 1 laktuloz ilave edilen sucuklar (3.24 log kob g $\left.{ }^{-1}\right)$ olduğu tespit edilmiş ve istatistik olarak da fark meydana gelmiştir $(p<0.05)$. 15. Gün sonunda ise maya-küf sayısı açısından en yüksek artışın \%1'lik örneklerde (3.24 log kob g ${ }^{-1}$ ' den 4.29 log kob g1'a) olduğu görülmüş, ancak örnekler arasında fark gözlenmemiştir ( $p>0.05)$. LAB sayıları incelendiğinde, fermantasyonun başlangıcında $4.77 \mathrm{log} \mathrm{kob} \mathrm{g}^{-1}$ olan sayının, 7. günde önemli bir artış gösterdiği (8.15-8.91 log kob $\mathrm{g}^{-1}$ ) belirlenmiş ancak örnekler arasında fark oluşturmadığı $(p>0.05)$ tespit edilmiştir. Fermantasyonun sonunda ise sucuklarda LAB sayıları 8.57 ila $9.55 \mathrm{log} \mathrm{kob} \mathrm{g}^{-1}$ olarak bulunmuş ve örneklerde istatistiki olarak fark oluşmuştur $(p<0.05)$. Laktuloz konsantrasyonunun artışı, LAB gelişimini teşvik ederek sayılarında artış meydana getirmiş ve en yüksek sayı \%2 ilaveli sucuklarda belirlenmiştir (9.55 log kob g $\left.{ }^{-1}\right)$. Bu durum SEM görüntülerinde de gözlenmiş olup, örneklerin SEM görüntüleri incelendiğinde (Şekil 1) yine \%2 laktuloz ilaveli sucuklarda yoğun olarak basil yapıda bakterilerin bulunduğu görülmüştür.

Tablo 4. Mikrobiyolojik Analiz Sonuçları ${ }^{1}\left(\log\right.$ kob g $\left.^{-1}\right)$ 
Table 4. Microbiological Analysis Results ${ }^{1}\left(\log\right.$ cfu $\left.^{-1}\right)$

\begin{tabular}{|c|c|c|c|c|c|}
\hline \multirow{2}{*}{ Analiz } & \multirow{2}{*}{ Gün } & \multicolumn{4}{|c|}{ Örnek } \\
\hline & & $\mathrm{A}$ & B & $\mathrm{C}$ & $\mathrm{D}$ \\
\hline \multirow{3}{*}{ Enterobacteriaceae } & $\overline{0}$ & 3.56 & & & \\
\hline & 7 & $1.63 \pm 0.72^{\mathrm{a}}$ & $2.21 \pm 0.15^{\mathrm{a}}$ & $2.02 \pm 0.18^{\mathrm{a}}$ & $1.97 \pm 0.25^{\mathrm{a}}$ \\
\hline & 15 & 0 & 0 & 0 & 0 \\
\hline \multirow{3}{*}{ ТАМВ } & 0 & 5.85 & & & \\
\hline & 7 & $3.69 \pm 0.14^{\mathrm{a}}$ & $3.66 \pm 0.12^{\mathrm{a}}$ & $3.82 \pm 0.12^{\mathrm{a}}$ & $3.78 \pm 0.14^{\mathrm{a}}$ \\
\hline & 15 & $4.29 \pm 0.89^{\mathrm{a}}$ & $3.84 \pm 0.37^{\mathrm{a}}$ & $3.54 \pm 0.24^{\mathrm{a}}$ & $3.93 \pm 0.30^{\mathrm{a}}$ \\
\hline \multirow{3}{*}{ Maya-Küf } & 0 & 4.15 & & & \\
\hline & 7 & $4.15 \pm 0.25^{\mathrm{a}}$ & $4.57 \pm 0.66^{\mathrm{a}}$ & $3.24 \pm 0.28^{\mathrm{b}}$ & $3.92 \pm 0.72^{\mathrm{ab}}$ \\
\hline & 15 & $4.00 \pm 0.09^{\mathrm{a}}$ & $3.50 \pm 0.16^{\mathrm{a}}$ & $4.29 \pm 0.39^{\mathrm{a}}$ & $3.96 \pm 1.92^{\mathrm{a}}$ \\
\hline \multirow{3}{*}{ LAB } & 0 & 4.77 & & & \\
\hline & 7 & $8.15 \pm 0.74^{\mathrm{a}}$ & $8.20 \pm 0.98^{\mathrm{a}}$ & $8.90 \pm 0.38^{\mathrm{a}}$ & $8.91 \pm 0.39^{\mathrm{a}}$ \\
\hline & 15 & $8.57 \pm 0.21^{\mathrm{b}}$ & $8.95 \pm 0.17^{\mathrm{ab}}$ & $9.30 \pm 0.35^{\mathrm{a}}$ & $9.55 \pm 0.23^{\mathrm{a}}$ \\
\hline
\end{tabular}

*A:Kontrol; B: \%0.5 laktuloz ilaveli; C: \%1laktuloz ilaveli; D: \%2 laktuloz ilaveli

${ }^{1}$ Değerler \pm standart sapmay ihtiva etmektedir. Sütunda aynı harflerle işaretlenen ortalamalar istatistiksel olarak birbirinden farklı değildir ( $p>0.05)$

*A:No lactulose added; B: 0.5\% lactulose added; C: 1\% lactulose added; D: 2\% lactulose added

${ }^{1}$ Values include \pm standard deviation. The averages marked with the same column in rows are not statistically different from each other $(p>0.05)$

Kargozari ve ark. (2014), İran'da tüketilen özel bir peynirden izole ettikleri 3 farklı kültür ilavesiyle fermente sucuk üretmişler ve bu sucukları 15 gün boyunca fermantasyona tabi tutmuşlardır. Olgunlaşma periyodunun sonunda örneklerde LAB sayılarının 8.96 ile 9.14 log kob g-1 arasında değiştiğini bildirmişlerdir. Bu sonuçların çalışmamıza yakın olduğu görülmektedir.

Başka bir çalışmada Ekici ve ark. (2015) farklı oranlarda siyah havuç ilave ederek sucuk üretmişler ve bu sucuklarda çeşitli analizler yürütmüşlerdir. 12 günlük olgunlaştırma periyodu sonunda sucuk örneklerinde TAMB sayısının 8.47-8.73 log kob g-1; LAB sayısının 8.36-8.71 log kob g ${ }^{-1}$ ve maya-küf sayısının ise 3.54-5.21 log kob $\mathrm{g}^{-1}$ arasında değiştiğini bildirmişlerdir. Çalışmada sucuklardaki LAB ve maya-küf sayılarının çalışmamızda elde edilen sonuçlarla benzer olduğu, TAMB sayısının ise çalışmamızdan yüksek olduğu görülmüştür. Öksüztepe ve ark. (2011) Elazığ'da satışa sunulan fermente sucukların kalite özelliklerini incelemişler ve sucuklarda TAMB, LAB ve maya-küf sayılarının ortalama olarak sırasıyla $8.75,8.56$ ve $3.08 \log \mathrm{kob} \mathrm{g}^{-1}$ düzeyinde bulunduğunu bildirmişlerdir. 


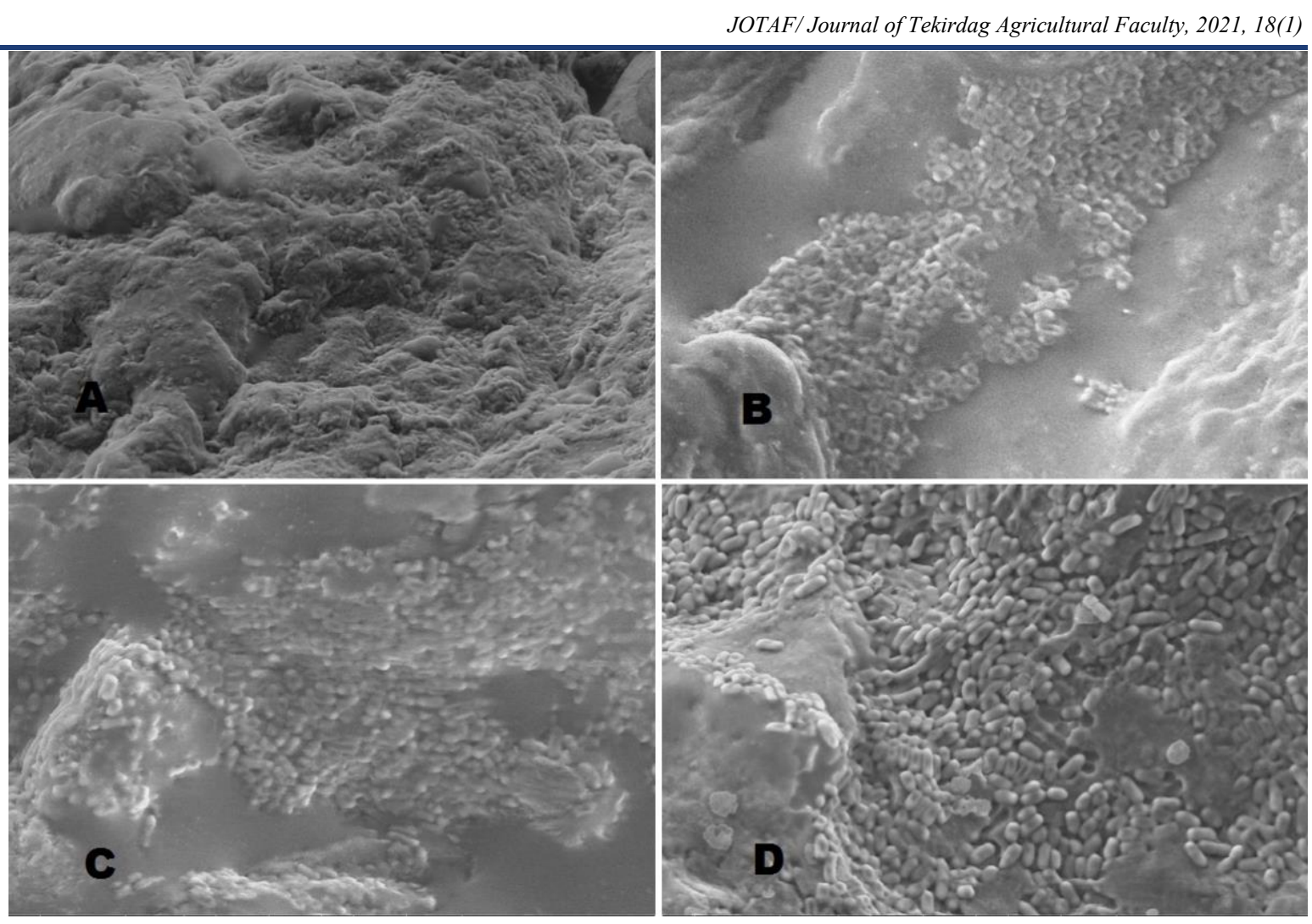

Figure 1. SEM Images of Sucuk Samples* (x10.000 magnified times)

*A:No lactulose added; B: 0.5\% lactulose added; C: $1 \%$ lactulose added; D: $2 \%$ lactulose added

\section{Şekil 1. Sucuk Örneklerinin SEM Görüntüleri* (x10.000 büyütme gücü ile)}

*A:Kontrol; B: \%0.5 laktuloz ilaveli; C: \%1laktuloz ilaveli; D: \%2 laktuloz ilaveli

Sucuk örneklerinin duyusal analiz bulguları Tablo 5'de verilmiştir. Laktuloz ilavesi sucukların duyusal özelliklerinde renk kriteri hariç farklılık meydana getirmemiştir. Duyusal paneli yapan grup tarafindan incelenen bütün duyusal kalite kriterleri (renk, koku, lezzet, doku, genel kabul) açısından en çok beğenilen grup \% 2 laktuloz ilaveli sucuk grubu olurken, en düşük puanı \% 1 laktuloz ilaveli sucuk grupları almıştır. Ürünlerin genel kabul puanları incelendiğinde sırasıyla ortalama $6.03 ; 5.69 ; 5.16 ; 6.07$ şeklinde puan dağılımı gözlenmiş, örnekler arasında istatistiki fark tespit edilmemiştir $(p>0.05)$.

Tablo 5. Sucuk Örneklerin Duyusal Analiz Puanlart ${ }^{1}$

Table 5. Sensorial Analysis Scores of Sucuks ${ }^{1}$

\begin{tabular}{ccccc}
\hline \multirow{2}{*}{ Duyusal Özellik } & \multicolumn{4}{c}{ Örnek $^{*}$} \\
\cline { 2 - 5 } & A & B & C & D \\
\hline Renk & $6.36 \pm 0.311^{\mathrm{ab}}$ & $4.99 \pm 0.848^{\mathrm{b}}$ & $3.30 \pm 0.601^{\mathrm{c}}$ & $6.60 \pm 0.304^{\mathrm{a}}$ \\
Koku & $6.19 \pm 0.02^{\mathrm{a}}$ & $5.77 \pm 0.516^{\mathrm{a}}$ & $4.91 \pm 0.388^{\mathrm{a}}$ & $6.28 \pm 0.318^{\mathrm{a}}$ \\
Tat & $6.04 \pm 0.254^{\mathrm{a}}$ & $5.88 \pm 0.417^{\mathrm{a}}$ & $5.29 \pm 0.134^{\mathrm{a}}$ & $6.11 \pm 0.247^{\mathrm{a}}$ \\
Doku & $5.58 \pm 0.502^{\mathrm{a}}$ & $5.51 \pm 0.714^{\mathrm{a}}$ & $4.78 \pm 0.275^{\mathrm{a}}$ & $5.71 \pm 0.219^{\mathrm{a}}$ \\
Genel Kabul & $6.03 \pm 0.226^{\mathrm{a}}$ & $5.69 \pm 0.487^{\mathrm{a}}$ & $5.16 \pm 0.035^{\mathrm{a}}$ & $6.07 \pm 0.289^{\mathrm{a}}$ \\
\hline
\end{tabular}

*A:Kontrol; B: \%0.5 laktuloz ilaveli; C: \%1laktuloz ilaveli; D: \%2 laktuloz ilaveli

${ }^{1}$ Değerler \pm standart sapmayı ihtiva etmektedir. Satırda aynı harflerle işaretlenen ortalamalar istatistiksel olarak birbirinden farklı değildir ( $p>0.05)$

*A:No lactulose added; B: $0.5 \%$ lactulose added; C: $1 \%$ lactulose added; D: $2 \%$ lactulose added

${ }^{1}$ Values include \pm standard deviation. The averages marked with the same letters in rows are not statistically different from each other $(p>0.05)$ 
Pehlivanoğlu ve ark. (2015), piyasada bulunan fermente sucukların çeşitli duyusal özelliklerini (görünüş, kesit yüzeyi, kıvam-yapı, aroma, genel kabul) incelemiş ve duyusal incelemede puanlama 5 üzerinden yapmışlardır. Araştırma sonunda ilgili parametreler sırasıyla ortalama olarak 4.66; 4.87; 4.83; 4.92 ve 4.82 şeklinde elde edilmiş ve sucukların duyusal açıdan iyi durumda oldukları belirlenmiştir. Yine başka bir çalışmada Ekici ve ark. (2015) ürettikleri fermente sucukları duyusal açıdan değerlendirmiş (1-9 puan aralığı) ve sonuçların çalışmamızla benzerlik taşıdığını bildirmişlerdir.

\section{Sonuç}

Laktuloz, laktozun izomerizasyonu sonucu oluşan bir disakkarit olup, çok değerli bir fonksiyonel maddedir. Bulunduğu ortamda probiyotik özellikteki yararlı bakterilerin gelişimini teşvik ederek sağlı̆̆a katkıda bulunabilmektedir. Aynı zamanda sindirim sisteminde bulunması durumunda buradaki yararlı bakterilerin de gelişimi hızlandırmaktadır. Laktulozun fermantasyon prosesi içeren pek çok gıdada bu özellikleri dolayısıyla kullanılmasının, yeni ürünlerin geliştirilmesi ve tüketime sunulması bakımından önemli katkılarda bulunacağ tahmin edilmektedir. Bütün bunları dikkate alarak yaptığımız çalışmada, farklı oranlarda laktuloz ilave edilerek sucuk üretilmiş ve laktulozun sucukların fermantasyon sürecini nasıl etkilediği ve kalite özelliklene olan etkisi incelenmiştir. Laktuloz ilavesi ürünlerde pişirme kaybını azaltmış, duyusal açıdan panele katılanlar da laktuloz ilaveli sucukları daha çok beğendiklerini ifade etmişlerdir. Diğer taraftan laktuloz ilavesi sucuların tekstürel özelliklerini değiştirmemiştir. Bununla birlikte laktuloz ilave edilen sucuklarda, fermantasyonun 15. Gününde LAB sayısının daha yüksek olduğu gözlenmiştir. Önemli bir et ürünü olan sucukta laktulozun kullanılmasının, ürünün kalite özelliklerinin geliştirilmesi açısından, teknolojik açıdan, ekonomik açıdan ve en önemlisi de sağlık açısından çok faydalı olacağı çalışmamızda elde edilen sonuçlarla örtüşmektedir. Bu nedenle laktuloz ve benzeri prebiyotik özellikli doğal ürünlerin, fermente sucuk ve benzeri et ve diğer gıda ürünlerinde kullanımı üzerine çalışmaların yaygınlaşması gerektiği de düşünülmektedir.

\section{Teșekkür}

Çalışmaya verdiği destekten dolayı Kırklareli Üniversitesi Bilimsel Araştırma Projeleri Koordinasyon Birimi'ne teşekkür ederiz (Proje no: KLU BAP 079). 


\section{Kaynakça}

Akalın, A.S. (2002). Laktuloz üretimi, gıda ve farmakoloji endüstrisinde kullanımı. Gıda 27(6): 475-478.

Aksu, M.I., Kaya, M. (2004). Effect of usage Urtica dioica L. on microbiological properties of sucuk, a Turkish dry-fermented sausage. Food Control 15:591-595.

Alpkent, Z., Göncü, A. (2005 Laktuloz ve kullanım alanları. Dünya Glda 12: 66-69.

Anonim (2019). Et, hazırlanmış et karışımları ve et ürünleri tebliği. Türk Gıda Kodeksi Tebliğ No: 2018/52.

Association of Official Analytical Chemists - AOAC (1984). Official methods of analysis. Centennial Edition. Association of Official Analytical Chemists, Washington D.C., USA.

Association of Official Analytical Chemists - AOAC (1990). Official methods of analyses of association of analytical chemist. Fifteen Edition, Washington DC, USA.

Bağdatlı, A.B., Kundakçı, A. (2013). Fermente et ürünlerinde probiyotik mikroorganizmaların kullanımı. C.B.U. Fen Bilimleri Dergisi 9 (1): 31-37.

Bilge, G. (2010). Sucukta üretim sırasında meydana gelen mikrobiyolojik ve biyokimyasal değișmelere üretim sıcaklı̆̆ının ve starter kültürün etkisi. (Yüksek Lisans Tezi) Ankara Üniversitesi Fen Bilimleri Enstitüsü, Ankara.

Bingol, E.B., Bostan, K., Varlik, C., Uran, H., Alakavuk, D.Ü., Sivri, N. (2015). Effects of chitosan treatment on the quality parameters of shrimp (Parapenaeus longirostris) during chilled storage. Turkish Journal of Fisheries and Aquatic Sciences 15: 821-831.

Bostan, K., Uğur, M., Çetin, Ö. (2001). Kanatlı etinden salam üretimi üzerine deneysel çalışmalar. Istanbul Üniversitesi Veteriner Fakültesi Dergisi 27(2): 631-644.

Bozkurt, H. (2007). Comparison of the effects of sesame and Thymbra spicata oil during the manufacturing of Turkish dry-fermented sausage. Food Control 18: 149-156.

Bozkurt, H., Erkmen, O. (2007). Effects of some commercial additives on the quality of sucuk (Turkish dry-fermented sausage). Food Chemistry 101: 1465-1473.

Dalmis, U., Soyer, A. (2008). Effect of processing methods and starter culture (Staphylococcus xylosus and Pediococcus pentosaceus) on proteolytic changes in Turkish sausages (sucuk) during ripening and storage. Meat Science 80: 345-354.

Dertli, E., Yilmaz, M.T., Tatlisu, N.B., Toker, O.S., Cankurt, H., Sagdic, O. (2016). Effects of in situ exopolysaccharide production and fermentation conditions on physicochemical, microbiological, textural and microstructural properties of Turkish-type fermented sausage (sucuk). Meat Science 121: 156-165.

Ekici, L., Ozturk, I., Karaman, S., Caliskan, O., Tornuk, F., Sagdic, O., Yetim, H. (2015). Effects of black carrot concentrate on some physicochemical, textural, bioactive, aroma and sensory properties of sucuk, a traditional Turkish dry-fermented sausage. $L W T$ - Food Science and Technology 62: 718-726.

Frei, C.B.F., Prudencio, E.S., Amboni, R.D.M.C., Pinto, S.S., Murakami, A.N.N., Murakami, F.S. (2012). Microencapsulation of bifidobacteria by spray drying in the presence of prebiotics. Food Research International 45: 306-312.

Geçgel, Ü., Yılmaz, İ., Ay, A., Apaydın, D., Dülger G.C. (2016). Soğuk pres yağlar ilave edilerek üretilen fermente sucukların fizikokimyasal özelliklerinin belirlenmesi. Tekirdağ Ziraat Fakültesi Dergisi 13(04): 1-11.

Gibson, G. R., Roberfroid, M. B. (1995) Dietary modulation of the human colonic microbiota: introducing the concept of prebiotics. The Journal of Nutrition 125: 1401-1412.

Gimeno, O., Astiasaran, I., Bello, J. (2001). Calcium ascorbate as a potential partial substitute for nacl in dry fermented sausages:effect on colour, texture and hygienic quality at different concentrations. Meat Science 57, 23-29.

Gökalp, H.Y., Ercoşkun, H., Çon, A.H. (1998). Fermente et ürünlerinde bazı biyokimyasal reaksiyonlar ve aroma üzerine etkileri. Pamukkale Üniversitesi Mühendislik Bilimleri Dergisi 4(3): 805-811.

Gokoglu, N., Yerlikaya, P., Uran, H., Topuz, O.K. (2010). The effect of modified atmosphere packaging on the quality and shelf life of frankfurter type-sausages. Journal of Food Quality 33 (2010): 367-380.

Gözübüyük, S.T., Özdemir, H. (2005). Ticari starter kültürlerin fermente Türk sucuklarının organoleptik kalite niteliklerine etkisi. Orlab Mikrobiyoloji Dergisi 2(12): 1-12.

Gülmez, M., Güven, A. (2002). Probiotik, prebiyotik ve sinbiyotikler. Kafkas Üniversitesi Veteriner Fakültesi Dergisi 8 (1): $83-89$

Hampikyan, H., Ugur, M. (2007). The effect of nisin on L. monocytogenes in Turkish fermented sausages (sucuks). Meat Science 76: $327-332$.

Kaban, G. (2010). Volatile compounds of traditional Turkish dry fermented sausage (sucuk). International Journal of Food Properties 13: 525-534.

Kara, R., Akkaya, L. (2010). Geleneksel ve ısıl işlem uygulanarak üretilen Türk sucuklarında Salmonella typhimurium'un gelişimi. Gıda Teknolojileri Elektronik Dergisi 5(3): 1-8. 
Kara, R., Akkaya, L., Gök, V., Gürler, Z., Müdüroğlu, R. (2012). Farklı oranlarda manda eti kullanılarak üretilen sucukların olgunlaşma ve depolama aşamalarındaki bazı özelliklerinin araştırılması. Kocatepe Veteriner Dergisi 5(1): 13-19.

Kargozari, M., Moini, S., Basti, A.A., Emam-Djomeh, Z., Gandomi, H., Martin, I.R., Ghasemlou, M., Carbonell-Barrachina, A.A. (2014). Effect of autochthonous starter cultures isolated from Siahmazgi cheese on physicochemical, microbiological and volatile compound profiles and sensorial attributes of sucuk, a Turkish dry-fermented sausage. Meat Science 97:104-114.

Kavas, G., Kavas, N. (2011). Laktulozun sağlık üzerindeki etkileri ve kullanım alanları. Dünya Gıda 11: 94-97.

Montilla, A., Castillo, M.D.D., Sanz, M.L., Olano, A. (2005). Egg shell as catalyst of lactose isomerisation to lactulose. Food Chemistry 90: 883-890.

Öksüztepe, G., Güran, H.S., İncili, G.K., Gül, S.B. (2011). Elazı̆̆g'da tüketime sunulan fermente sucukların mikrobiyolojik ve kimyasal kalitesi. Fırat Üniversitesi Să̆llk Bilimleri Veteriner Deegisi 25(3): 107-114.

Pehlivanoğlu, H., Nazlı, B., İmamoğlu, H., Çakır, B. (2015). Piyasada fermente sucuk olarak satılan ürünlerin kalite özelliklerinin saptanması ve geleneksel Türk fermente sucuğu ile karşılaştırılması. Ístanbul Üniversitesi Veteriner Fakültesi Dergisi 41(2): $191-198$.

Soyer, A., Ertas, A.H., Uzumcuoglu, U. (2005). Effect of processing conditions on the quality of naturally fermented Turkish sausages (sucuks). Meat Science 69: 135-141.

TSE (2002): TS 1070: Türk Sucuğu. Türk Standartları Enstitüsü, Ankara,

TSE (2014a). TS EN ISO 4833-2: Gıda zinciri mikrobiyolojisi-Mikroorganizmaların sayımı için yatay yöntem. Türk Standartları Enstitüsü, Ankara.

TSE (2014b). TS ISO 21527-2: Gıda ve hayvan yemleri mikrobiyolojisi-Maya ve küflerin sayımı için yatay yöntem. Türk Standartları Enstitüsü, Ankara.

TSE (2018). TS EN ISO 21528-2: Gıda zinciri mikrobiyolojisi-Enterobacteriaceae'nın tespiti ve sayımı için yatay yöntem. Türk Standartları Enstitüsü, Ankara.

Uren, A., Babayigit, D. (1996). Determination of Turkish-type fermented colour by a reflectance method. Food Chemistry 57(4): 561-567.

Yilmaz, M. T., Dertli, E., Toker, O. S., Tatlisu, N. B., Sagdic, O., Arici, M. (2016). Effect of in situ exopolysaccharide production on physicochemical, rheological, sensory and microstructural properties of yoghurt drink, ayran: An optimization study based on fermentation kinetics. Journal of Dairy Science 98: 1604-1624, 2015.

Yılmaz, M.T., Toker, O.S., Tatlisu, N.B., Arıc1, M., Dertli, E. (2016). Effect of in situ exopolysaccharide production on sensory properties of Turkish-type fermented sausage. Sigma Journal Engineering and Natural Sciences 34(2): 261-267. 